\title{
PENGARUH PELATIHAN TERHADAP KINERJA KARYAWAN PADA PT. PERMATA NIAGA CABANG PEMATANGSIANTAR
}

\author{
Oleh: \\ Vincent Intan \\ S1 Manajemen \\ Darwin Lie, Marisi Butarbutar, Efendi
}

\begin{abstract}
Tujuan penelitian ini adalah untuk mengetahui: 1) Gambaran pelatihan dan kinerja karyawan pada PT Permata Niaga Cabang Pematangsiantar. 2) Pengaruh pelatihan terhadap kinerja karyawan pada PT Permata Niaga Cabang Pematangsiantar.

Penelitian ini menggunakan metode deskriptif kualitatif dan deskriptif kuantitatif. Populasi pada penelitian ini ialah karyawan PT Permata Niaga Cabang Pematangsiantar yang berjumlah 32 orang. Variabel bebas pada penelitian ini ialah pelatihan, dan kinerja karyawan sebagai variabel terikatnya. Pengumpulan data dilakukan dengan observasi, kuesioner, wawancara dan dokumentasi. Teknik analisis yang digunakan ialah regresi linier sederhana, koefisien korelasi dan determinasi, dan pengujian hipotesis.

Hasil penelitian dapat disimpulkan sebagai berikut: 1) Pelatihan sudah baik dan kinerja karyawan PT. Permata Niaga Cabang Pematangsiantar sudah tinggi. 2) Hasil pengujian regresi adalah $\hat{Y}=21,448+0,692 X$, berarti ada pengaruh positif pelatihan terhadap kinerja karyawan. 3) Tinggi rendahnya kinerja karyawan dapat dijelaskan oleh pelatihan sebesar 69,7 persen. 4) Hipotesis Ho ditolak dan Ha diterima, artinya pelatihan berpengaruh positif dan signifikan terhadap kinerja karyawan pada PT Permata Niaga Cabang Pematangsiantar.

Adapun saran dari penelitian ini bahwa untuk meningkatkan pelatihan, diperlukan pemberian pelatihan kepada karyawan senior dalam hal menjadi seorang pelatih untuk karyawan baru dan pemberian motivasi kepada para peserta pelatihan. Untuk meningkatkan kinerja karyawan sebaiknya perusahaan memberikan sanksi yang tegas kepada karyawan yang terlambat, mengadakan rapat setiap minggu serta kegiatan olahraga untuk meningkatkan kerjasama antara pimpinan dan karyawan, dan memotivasi semua karyawan dalam hal penyelesaian pekerjaan.
\end{abstract}

Kata Kunci: Pelatihan dan Kinerja Karyawan

The purpose of this research is to examine an anlysis of: 1) The description of the training and the employee performance at PT Permata Niaga Branch Office Pematangsiantar. 2) The influence of the training on employee performance at PT Permata Niaga Branch Office Pematangsiantar.

This research is done by using quantitative descriptive and qualitative descriptive. The population in this research are the 32 employee of PT Permata Niaga Branch Office Pematangsiantar. The research variable consisted of independent variable in the form of the training, and employee performance as the dependent variable. Data was collected through observation, questionnaires, interviews and documentation. Data analysis technic is using simple linear regression, coefficient of correlation and determination, and hypothesis test.

The result of this research showed us: 1) The training already good and employee productivity already high. 2) The results of regression testing is $\hat{Y}=21,448+0,692 X$, means this research have a positive between training and employee performance 3) The level of employee performance can be explained by training process by 69,7 percent. 4) Hypothesis Ho is rejected and ha is accepted, means training have a positive and significantly to employee performance on PT Permata Niaga Branch Office Pematangsiantar.

The suggestion from this study that in order to improve the training process, it is necessary to giving training to senior employee in training new employee and providing motivation to the trainess. To increase the employee performance need for imposing sanctions on employees who are late, have conference every week and conduct cooperative activities to increase cooperation between management and employee and providing motivation to employee in terms of job completion.

Key word: Training and Employee Performance

\section{A. PENDAhuluan}

\section{Latar Belakang Masalah}

PT Permata Niaga Cabang Pematangsiantar merupakan distributor di Kota Pematangsiantar dalam penyaluran produk dari PT Ceres. Agar kegiatan perusahaan dapat terlaksana dengan baik, maka karyawan harus diberi bekal pengetahuan dan keterampilan yang cukup. Dengan pengetahuan dan keterampilan tersebut diharapkan dapat mendorong kinerja karyawan yang akan memberikan pengaruh dalam mencapai tujuan perusahaaan.

Fenomena kinerja di PT Permata Niaga Cabang Pematangsiantar diukur melalui faktor yang mempengaruhinya seperti kemampuan individu, tingkat usaha yang dicurahkan dan dukungan organisasi. Kinerja karyawan PT Permata Niaga Cabang Pematangsiantar bisa dikatakan belum optimal. Hal tersebut dikarenakan pada tingkat kedisiplinan karyawan yang kurang diterapkan 
karena masih ada karyawan yang datang tidak tepat pada waktu jam kerja, tingkat usaha yang dicurahkan yaitu dalam hal bekerja sama antar rekan kerja serta penyelesaian pekerjaan tepat pada waktunya masih belum optimal. berikut:

Hal tersebut dapat ditunjukkan melalui tabel

Tabel 1

Fenomena Kinerja Karyawan Pada PT Permata Niaga Cabang Pematangsiantar

\begin{tabular}{|c|c|c|c|c|c|c|}
\hline $\begin{array}{l}\text { Ind datar Kauja } \\
\text { Kangagan }\end{array}$ & ST & $\mathrm{T}$ & $s$ & R & SR & Sumla: \\
\hline $\begin{array}{l}\text { 1. Keasmpas } \\
\text { ipcosion }\end{array}$ & $31,25 \%$ & $62.5 \%$ & $625 \%$ & 0 & 0 & $100 \% / 2$ \\
\hline $\begin{array}{l}2 \text { Tingat Lista yang } \\
\text { digathon }\end{array}$ & $4,62 \%$ & $13,75 \%$ & $15,63 \%$ & 0 & 0 & $100 \%:$ \\
\hline 3. Dikngasogrisg: & $43,9 \%$ & $53,12 \%$ & $3,13 \%$ & 0 & 0 & $100 \%$ \\
\hline
\end{tabular}

Sumber: Hasil wawancara dengan pimpinan

Banyak faktor yang dapat mempengaruhi kinerja karyawan seperti penempatan kerja, hubungan antar rekan kerja, kompensasi, promosi dan salah satunya adalah pelatihan. Kegiatan pelatihan karyawan yang diberikan PT Permata Niaga Cabang Pematangsiantar diharapkan dapat mendorong kinerja yang optimal. Materi pelatihan yang diberikan sesuai dengan kepentingan kerja dan diberikan dengan menggunakan metode on the job serta metode demonstrasi dan contoh. Para senior digunakan sebagai instruktur dalam memberikan pelatihan kepada karyawan baru dan untuk karyawan lama, instruktur yang memberikan pelatihan adalah yang berpengalaman. Para peserta pelatihan yaitu karyawan yang berada di perusahaan, tempat pelatihan untuk karyawan yang lama yaitu berada di lokasi perusahan sedangkan tempat atau lokasi pelatihan bagi karyawan baru yaitu berada di luar perusahaan.

\section{Rumusan Masalah}

a. Bagaimana gambaran pelatihan dan kinerja karyawan pada PT Permata Niaga Cabang Pematangsiantar?

b. Bagaimana pengaruh pelatihan terhadap kinerja karyawan pada PT Permata Niaga Cabang Pematangsiantar?

\section{Tujuan Penelitian}

a. Untuk mengetahui gambaran pelatihan dan kinerja karyawan pada PT Permata Niaga Cabang Pematangsiantar.

b. Untuk mengetahui pengaruh pelatihan terhadap kinerja karyawan pada PT Permata Niaga Cabang Pematangsiantar.

\section{Metode Penelitian}

Lokasi penelitian ini adalah PT Permata Niaga Cabang Pematangsiantar yang beralamat di Jalan Asahan Kompleks Megaland Blok CC No. 1 Pematangsiantar. Pada penelitian ini yang menjadi populasi adalah seluruh karyawan di PT Permata Niaga Cabang Pematangsiantar sebanyak 32 orang. Mengingat populasi dibawah 100 orang dan kurangnya waktu dan tenaga penulis maka penelitian ini menggunakan populasi yang sama dengan sampel.

Adapun Desain penelitian yang digunakan dalam penulisan skripsi ini adalah Penelitian Kepustakaan (Library Research) dan Penelitian Lapangan (Field Research). Teknik pengumpulan data yang dilakukan penulis dalam penelitian ini adalah berupa Observasi, Kuesioner, Wawancara dan Dokumentasi. Adapun jenis data yang digunakan dalam penelitian ini adalah jenis data kualitatif dan data kuantitatif. Hasil data yang diperoleh dari lapangan akan dianalisis secara deskriptif baik bersifat kualitatif dan kuantitatif.

\section{B. LANDASAN TEORI}

1. Manajemen Sumber Daya Manusia

Menurut Dessler (2003:2), manajemen sumber daya manusia adalah kebijakan dan cara-cara yang dipraktekkan dan berhubungan dengan pemberdayaan manusia atau aspek-aspek sumber daya manusia dari sebuah manajemen termasuk perekrutan, seleksi, pelatihan, penghargaan dan penilaian. Sedangkan menurut Mondy (2008:4), manajemen sumber daya manusia adalah pemanfaatan para individu untuk mencapai tujuantujuan organisasi. Dari uraian diatas dapat disimpulkan manajemen sumber daya manusia adalah proses pendayagunaan sumber daya manusia yang dilakukan melalui pengaplikasian fungsi dari manajemen sumber daya manusia seperti perencanaan sumber daya manusia, rekrutmen dan seleksi, pengembangan karir, pemberian kompensasi, keselamatan dan kesehatan kerja, pelatihan dan pengembangan, promosi, dan pemutusan hubungan kerja, sehingga mampu memberikan kontribusi secara efektif dan efisien sesuai dengan harapan usaha perorangan, badan usaha, perusahaan, lembaga, maupun instansi.

Menurut Mondy (2008:4), fungsi MSDM, yaitu:

a. Penyediaan Staf, merupakan suatu proses yang menjamin suatu organisasi selalu memiliki jumlah karyawan yang tepat dengan keahliankeahlian yang memadai dalam pekerjaanpekerjaan yang tepat, pada waktu yang tepat, untuk mencapai tujuan organisasi. Penyediaan staf mencakup analisis pekerjaan, perencanaan sumber daya manusia, perekrutan, dan seleksi.

b. Pengembangan Sumber Daya Manusia (SDM), adalah fungsi MSDM utama yang tidak hanya terdiri dari pelatihan dan pengembangan namun juga aktivitas-aktivitas perencanaan dan pengembangan karier individu, pengembangan organisasi serta manajemen dan penilaian kinerja. Pelatihan dirancang untuk memberi para pembelajar sejumlah pengetahuan dan keterampilan yang diperlukan untuk pekerjaan mereka saat ini. Pengembangan melibatkan pembelajaran yang beranjak ke luar pekerjaan saat ini dan memiliki fokus lebih berjangka panjang.

c. Kompensasi, kompensasi mencakup semua imbalan total yang diberikan kepada karyawan 
sebagai timbal balik untuk jasa mereka. Imbalan atau kompensasi tersebut dapat dibagi menjadi kompensasi finansial langsung, tidak langsung dan non finansial.

d. Keselamatan dan Kesehatan, keselamatan adalah perlindungan bagi para karyawan dari luka-luka yang disebabkan kecelakaan-kecelakaan yang terkait dengan pekerjaan. Kesehatan adalah bebasnya para karyawan dari sakit secara fisik atau emosi.

Menurut Simamora (2002:8), ada empat tujuan manajemen sumber daya manusia, yaitu:

a. Tujuan sosial, tujuan sosial manajemen sumber daya manusia adalah organisasi bertanggung jawab secara sosial dan etis terhadap kebutuhan dan tantangan masyarakat. Organisasi bisnis diharapkan dapat meningkatkan kualitas masyarakat dan membantu memecahkan masalah sosial.

b. Tujuan organisasional, tujuan organisasional manajemen sumber daya manusia adalah sasaran formal organisasi yang dibuat untuk membantu organisasi mencapai tujuannya. Departemen sumber daya manusia dibentuk untuk membantu para manajer mencapai tujuan organisasi.

c. Tujuan fungsional, merupakan tujuan untuk mempertahankan kontribusi departemen manajemen sumber daya manusia pada tingkat yang sesuai dengan kebutuhan organisasi. Pemborosan sumber daya akan terjadi jika departemen sumber daya manusia terlalu canggih maupun kurang canggih dibandingkan dengan kebutuhan organisasi.

d. Tujuan pribadi, adalah tujuan individu dari setiap anggota organisasi yang hendak dicapai melalui aktivitasnya di dalam organisasi. Jika tujuan pribadi dan tujuan organisasi tidak cocok atau tidak harmonis, maka karyawan barangkali memilih untuk menarik diri dari perusahaan.

\section{Pelatihan}

Menurut Mondy (2008:210), pelatihan adalah aktivitas-aktivitas yang dirancang untuk memberi para pembelajar pengetahuan dan keterampilan yang dibutuhkan untuk pekerjaan mereka pada saat ini. Menurut Flippo (2000:54), pelatihan adalah tindakan untuk meningkatkan pengetahuan dan kecakapan sumber daya dalam suatu organisasi untuk melaksanakan pekerjaan tertentu. Menurut Mathis dan John (2006:301), pelatihan adalah suatu proses dimana orang mendapatkan kapabilitas untuk membantu pencapaian tujuan organisasional. Dari uraian diatas dapat disimpulkan bahwa pelatihan merupakan bagian dari investasi sumber daya manusia untuk meningkatkan kemampuan serta keterampilan kerja seorang karyawan untuk mencapai tujuan perusahaan. Pelatihan ini digunakan dalam menghadapi tugas serta pekerjaan mereka pada saat ini.

Menurut Rivai (2004:240), faktor-faktor yang mempengaruhi pelatihan yaitu sebagai berikut: a. Materi yang diberikan, materi yang diberikan disusun dari estimasi kebutuhan tujuan latihan.
Kebutuhan tujuan pelatihan dijelaskan dalam bentuk pengajaran keahlian khusus dan menyajikan pengetahuan yang diperlukan oleh peserta pelatihan.

b. Instruktur, instruktur yang digunakan dalam memberikan pelatihan mencari sumber-sumber informasi yang lain yang mungkin berguna dalam mengidentifikasi kebutuhan pelatihan.

c. Peserta pelatihan, peserta pelatihan tentunya harus diseleksi berdasarkan persyaratan tertentu dan kualifikasi yang sesuai, selain itu sangat penting untuk memperhitungkan dan mengetahui tipe pekerja dan jenis pekerja yang akan dilatih.

d. Tempat dan fasilitas, tempat dan fasilitas yang digunakan pada saat proses pembelajaran harus dapat mendukung pelaksanan pelatihan sehingga memberikan rasa nyaman.

\section{Kinerja}

Menurut Rivai (2004:604), kinerja merupakan perilaku yang nyata yang ditampilkan setiap orang sebagai prestasi kerja yang dihasilkan oleh karyawan sesuai dengan perannya dalam perusahaan. Sedangkan menurut Mathis dan John (2006:113), kinerja adalah segala sesuatu yang dilakukan dan tidak dilakukan oleh karyawan. Menurut Hasibuan (2000:87), kinerja adalah hasil kerja yang dicapai seseorang dalam melaksanakan tugas-tugas yang dibebankan kepadanya yang didasarkan atas kecakapan, pengalaman dan kesungguhan waktu. Dari beberapa pendapat, dapat disimpulkan bahwa kinerja merupakan hasil kerja yang dicapai seorang karyawan dalam melaksanakan tugas yang dibebankan kepadanya atas dasar kecakapan, pengalaman dan ketepatan waktu dalam hal kemampuan bekerja secara efektif dan efisien.

Menurut Mathis dan John (2006:113) terdapat tiga faktor yang mempengaruhi kinerja karyawan, yaitu:

a. Kemampuan individu, kemampuan individu karyawan ini mencakup bakat, minat dan faktor kepribadian. Tingkat kemampuan individual adalah bahan mentah yang dimiliki karyawan seperti pengetahuan, pemahaman, kemampuan, kecakapan interpersonal, dan kecakapan bisnis. Dengan demikian, kemungkinan seorang karyawan akan memiliki kemampuan individual yang cukup.

b. Tingkat usaha yang dicurahkan, usaha dari karyawan adalah etika kerja, kehadiran dan motivasinya. Tingkat usaha merupakan gambaran motivasi yang diperlihatkan karyawan untuk menyelesaikan pekerjaan yang baik. Oleh karena itu, walaupun karyawan memiliki kemampuan individu untuk mengerjakan pekerjaan, tetapi tidak akan bekerja tanpa tingkat usaha yang rendah.

c. Dukungan organisasi, dalam dukungan organisasional artinya fasilitas apa yang perusahaan sediakan bagi karyawan dapat berupa pelatihan, peralatan teknologi, dan manajemen. 
4. Hubungan Pelatihan Terhadap Kinerja Nasution (2002:71) mengatakan bahwa pelatihan adalah suatu proses mengajar dengan mempergunakan teknik dan metode tertentu, guna meningkatkan keterampilan dan kemampuan kerja seseorang. Sedangkan Menurut Flippo (2000:54), Pelatihan adalah tindakan untuk meningkatkan pengetahuan dan kecakapan sumber daya dalam suatu organsiasi untuk melaksanakan pekerjaan tertentu. Jadi dapat disimpulkan bahwa pelatihan memiliki hubungan dengan kinerja, dimana pelatihan merupakan suatu tindakan atau proses mengajar dengan menggunakan teknik dan metode tertentu dalam hal untuk meningkatkan pengetahuan, keterampilan, kecakapan, serta kemampuan seseorang dalam melaksanakan pekerjaaannya.

Seperti kita ketahui bahwa latihan kerja atau pelatihan merupakan. kegiatan perusahaan dengan maksud dapat memperbaiki dan mengembangkan sikap, tingkah laku, keterampilan, dan pengetahuan para karyawan sesuai keinginan perusahaan yang bersangkutan. Apabila karyawan telah dilatih maka mereka akan memiliki kemampuan dan keterampilan yang lebih baik, sehingga mereka mampu bekerja lebih efektif dan efisien, dan akhirnya karyawan tersebut akan memperoleh kinerja yang baik.

\section{PEMBAHASAN}

\section{Analisa}

\section{a. Analisa Deskriptif Kualitatif}

Analisis deskriptif kualitatif digunakan untuk mendapatkan gambaran atau deskripsi mengenai Pengaruh Pelatihan Terhadap Kinerja Karyawan Pada PT Permata Niaga Cabang Pematangsiantar. Sesudah pengujian data, maka langkah selanjutnya peneliti melakukan pengkajian analisis kualitatif sebagai gambaran fenomena dari variabel penelitian pada saat sekarang ini. Adapun penetapan kriteria nilai rata - rata jawaban dari responden tesebut dimasukkan dalam kelas-kelas interval sebagai berikut:

Tabel 2

Nilai Interval dan Kategori Jawaban Responden

\begin{tabular}{|c|c|c|}
\hline \multirow[b]{2}{*}{ Nilai Interval } & \multicolumn{2}{|c|}{ Kateguri } \\
\hline & Pelatihan & Kinerja Karyawan \\
\hline $1,00 \cdot 1,80$ & Sungx Tidak Setriju & Samgat Tiagej \\
\hline $1.81-2.60$ & Tidak Setuis & Ingsi \\
\hline $201-3,40$ & Kurang Setuja & Sodang \\
\hline $3,41 \cdot 4,20$ & Setais & Readah \\
\hline $4,20-5,00$ & Sangat Senuin & Samat Rentah \\
\hline
\end{tabular}

Sumber: Hasil Pengolahan Data

\section{1) Pelatihan Pada PT Permata Niaga Cabang Pematangsiantar}

Pelatihan sangat penting bagi suatu perusahaan karena dapat meningkatkan kinerja karyawannya. PT Permata Niaga Cabang Pematangsiantar telah memberikan pelatihan kepada para karyawannya. Dalam memberikan pelatihan kepada karyawannya, perusahaan menggunakan metode on the job serta metode demonstrasi dan contoh.

Materi pelatihan yang diberikan sesuai dengan kepentingan kerja masing-masing karyawan. Orang yang memberikan pelatihan memiliki pengetahuan serta keterampilan tentang apa yang akan diajarkan kepada karyawan baru. Dalam hal ini, instruktur yang digunakan dalam melatih karyawan yang baru adalah karyawan yang sudah lama bekerja di perusahaan yaitu karyawan senior sedangkan untuk karyawan yang lama, instruktur yang memberikan pelatihan harus seseorang yang ahli dan paham betul apa yang diperlukan oleh karyawan lama tersebut.

Para peserta pelatihan yaitu karyawan yang berada PT. Permata Niaga Cabang Pematangsiantar. Tempat pelatihan untuk karyawan yang lama yaitu berada di lokasi perusahan sedangkan tempat atau lokasi pelatihan bagi karyawan baru yaitu berada di luar perusahaan Pelatihan yang diberikan kepada karyawan dapat meningkatkan kemampuan serta keterampilan karyawan yang berada di perusahaan sehingga kinerja yang dihasilkan dapat lebih ditingkatkan. Dengan diberikannya pelatihan tersebut maka karyawan akan lebih memahami dan mengerti akan pekerjaannya sehingga setiap pekerjaan yang dilakukan akan berjalan lancar dan tingkat kinerjanya akan semakin meningkat. Pelaksanaan pelatihan yang dilakukan di PT Permata Niaga Cabang Pematangsiantar dilakukan ketika ada karyawan baru yang akan masuk bekerja di perusahaan dan ketika karyawan lama akan menduduki posisi baru.

Dari tabel data rekapitulasi jawaban responden mengenai pelatihan dapat dilihat bahwa pada materi yang diberikan sesuai dengan kebutuhan kerja poin pertama diperoleh nilai rata-rata sebesar 3,41 dan dikategorikan setuju, karena pada saat pelatihan, karyawan mempelajari apa yang akan digunakan pada saat mereka bekerja. Pada poin kedua menunjukkan bahwa materi yang didapat, belum pernah diketahui oleh peserta pelatihan dikategorikan setuju dengan nilai rata-rata sebesar 4,03 karena materi pembelajaran yang diajarkan kepada mereka memang belum diketahui oleh karyawan dan materi yang didapat pada saat mengikuti pelatihan dipergunakan untuk kebutuhan kerja mereka masing-masing.

Pada indikator kedua yaitu instruktur, hasil kuesioner poin pertama yaitu instruktur yang memberikan materi adalah ahli dibidangnya diperoleh nilai rata-rata jawaban responden sebanyak 4,03 dikategorikan setuju karena instruktur yang memberikan pelatihan kepada karyawan tahu betul apa yang akan dibutuhkan oleh karyawan tersebut. Pada poin kedua setiap instruktur dalam menjelaskan materi mudah dimengerti diperoleh nilai rata-rata sebesar 3,41 dikategorikan setuju karena karyawan yang menerima pelatihan mudah menangkap materi yang diajarkan oleh instruktur. Sedangkan pada poin ketiga para senior yang ditunjuk sebagai instruktur mampu memberikan pelatihan sesuai dengan kebutuhan karyawan baru diperoleh nilai rata-rata 3,25 dikategorikan kurang setuju karena karyawan yang mengikuti pelatihan merasa karyawan senior tidak ahli dalam memberikan pelatihan kepada karyawan baru.

Dari hasil jawaban karyawan pada indikator ketiga yaitu peserta yang mengikuti pelatihan 
diperoleh nilai rata-rata sebesar 3,25 dikategorikan kurang setuju karena minat para karyawan dalam mengikuti pelatihan kurang tinggi. Pada poin kedua diperoleh nilai rata-rata sebesar 3,34 dikategorikan kurang setuju karena para karyawan yang mengikuti pelatihan tidak berusaha meningkatkan kemampuan mereka masing-masing.

Poin pertama pada indikator tempat dan fasilitas dari hasil kuesioner diperoleh rata-rata jawaban karyawan sebanyak 3,56 dikategorikan setuju karena untuk karyawan baru, lokasi pelatihan disediakan di dalam areal perusahaan sedangkan untuk karyawan yang lama, lokasi pelatihan berada di luar perusahaan. Pada poin kedua diperoleh nilai rata rata sebesar 3,56 dikategorikan setuju. Dikatakan demikian karena suasana tempat pelatihan bagi karyawan baru sangat nyaman karena suasana nyaman tersebut didapat karena karyawan senior yang memberikan pelatihan kepada karyawan baru mempunyai tata krama yang baik. Pada poin ketiga diperoleh nilai rata-rata sebesar 4,03 dikategorikan setuju karena para karyawan yang mendapatkan pelatihan diberikan semua fasilitas yang diperlukan seperti komputer, akses internet yang cepat, alat-alat tulis, alat peraga. Ini semua diperlukan dalam memperlancar proses pelatihan yang diberikan kepada karyawan. Pada poin keempat diperoleh nilai rata-rata sebesar 3,94 dikategorikan setuju karena lokasi tempat dilaksanakan pelatihan mudah dijangkau oleh karyawan. Sedangkan pada poin terakhir diperoleh nilai rata-rata sebesar 3,94 dinilai setuju menurut interval karena ruangan tempat dilaksanakan proses pelatihan sangat nyaman karena di dalam ruangan tempat dilaksanakan pelatihan terdapat AC sehingga para karyawan yang mengikuti pelatihan tidak kepanasan, sehingga karyawan yang mengikuti pelatihan.

Dari semua hasil indikator tersebut dapat disimpulkan bahwa faktor-faktor pelatihan dinilai dengan nilai rata-rata 3,65 hal ini karena pelatihan akan memberikan dampak yang positif terhadap setiap karyawan dalam melaksanakan tugas dan kewajibannya. Pada tabel tersebut diperoleh nilai rata tertinggi yaitu 4,03 pada indikator materi yang diberikan pada poin kedua, kemudian pada indikator instruktur pada poin pertama dan indikator tempat dan fasilitas poin ketiga. Namun pada indikator instruktur pada poin ketiga dan pada indikator peserta poin pertama belum optimal dikarenakan nilai rata-rata yang diperoleh sebesar 3,25 yang dikategorikan kurang setuju.

\section{2) Kinerja Karyawan PT Permata Niaga Cabang Pematangsiantar}

Kinerja merupakan hasil kerja yang dicapai seorang karyawan dalam melaksanakan tugas yang dibebankan kepadanya atas dasar kecakapan, pengalaman dan ketepatan waktu dalam hal kemampuan bekerja secara efektif dan efisien. Untuk dapat memperoleh kinerja yang baik, berarti kemampuan dan keterampilan yang dimiliki oleh para karyawan perusahaan harus baik pula, dan hal ini akan terjadi jika diadakan pelatihan yang ditujukan untuk para karyawan. Kinerja pada PT Permata Niaga Cabang Pematangsiantar ditandai oleh faktor yang mempengaruhi seperti kemampuan individu, tingkat usaha yang dicurahkan dan dukungan organisasi.

Seperti kita ketahui bahwa latihan kerja atau pelatihan merupakan kegiatan perusahaan dengan maksud dapat memperbaiki dan mengembangkan sikap, tingkah laku, keterampilan, dan pengetahuan para karyawan sesuai keinginan perusahaan yang bersangkutan. Apabila karyawan telah dilatih maka mereka akan memiliki kemampuan dan keterampilan yang lebih baik, sehingga mereka mampu bekerja lebih efektif dan efisien, dan akhirnya karyawan tersebut akan mempunyai kinerja yang baik pula.

Dari tabel data rekapitulasi jawaban responden mengenai kinerja dapat dilihat bahwa pada indikator pertama nilai rata-ratanya sebesar 4,34 pada poin pertama dikategorikan sangat tinggi karena setiap karyawan selalu menyelesaikan semua pekerjaan mereka dengan baik sesuai dengan standar kerja yang telah ditentukan perusahaan. Semua karyawan bertanggung jawab terhadap tugas serta pekerjaannya. Pada poin kedua nilai rata-rata yang diperoleh sebesar 4,31 dikategorikan sangat tinggi, karena setiap karyawan akan selalu mengutarakan pendapat atau opini kepada perusahaan apabila mengalami suatu permasalahan. Dengan demikian, akan tercipta hubungan yang baik antar sesama rekan kerja. Pada poin ketiga diperoleh nilai rata-rata sebesar 4,31 dikategorikan sangat tinggi karena setiap karyawan mampu menyelesaikan tugas dan pekerjaannya dengan baik. Sedangkan pada poin terakhir memperoleh nilai rata-rata sebesar 4,25 dikategorikan sangat tinggi karena karyawan hadir tepat waktu di kantor.

Pada indikator kedua poin pertama nilai ratarata sebesar 4,34 yang dikategorikan sangat tinggi karena karyawan dapat menyelesaikan pekerjaan mereka masing-masing dengan cara yang berbeda sehingga pekerjaan lebih mudah diselesaikan. Pada poin kedua diperoleh nilai rata-rata 4,22 dikategorikan sangat tinggi, karena apabila terjadi suatu permasalahan di perusahaan maka semua karyawan akan bekerjasama menyelesaikan permasalahan tersebut. Pada poin ketiga nilai rataratanya 4,25 dikategorikan sangat tinggi karena semua karyawan saling bertukar pikiran apabila terjadi suatu permasalahan sehingga dapat menciptakan suasana yang harmonis dalam lingkungan perusahaan. Pada poin keempat diperoleh nilai rata-rata sebesar 4,38 dikategorikan sangat tinggi karena semua karyawan harus mempunyai hubungan yang baik dengan pimpinan perusahaan, dengan demikian apa yang perlu diutarakan dapat langsung dibicarakan kepada pimpinan. Sedangkan pada poin terakhir diperoleh nilai rata-rata sebesar 4,22 dikategorikan sangat tinggi karena semua karyawan selalu melakukan tugas dan pekerjaan dengan baik sesuai dengan standar kerja yang telah ditentukan oleh perusahaan.

Pada indikator ketiga poin pertama diperoleh nilai rata-rata sebesar 4,41 yang dikategorikan sangat 
tinggi karena apabila karyawan yang mempunyai kinerja yang baik maka akan mendapatkan apresiasi dari pimpinan berupa penghargaan atau promosi jabatan. Pada poin kedua diperoleh nilai rata-rata sebesar 4,31 yang dikategorikan sangat tinggi karena fasilitas yang digunakan seperti komputer, printer, jaringan internet mendukung sehingga pekerjaan dapat diselesaikan dengan mudah. Kemudian pada poin ketiga diperoleh nilai rata-rata sebesar 4,38 yang dikategorikan sangat tinggi kareı perusahan mendukung program-progran meningkatkan kemampuan karyawannya

Dari seluruh uraian diatas dapat disimpulkan bahwa kinerja karyawan yang dinilai dari kemampuan individu, tingkat usaha yang dicurahkan, dan dukungan organisasi dinilai sangat tinggi, dapat dilihat dari nilai rata-rata keseluruhan yang diperoleh sebesar 4,31. Adapun nilai rata-rata tertinggi yaitu terdapat pada indikator dukungan organisasi poin pertama sebesar 4,41. Namun terdapat nilai terendah 4,22 terdapat pada indikator tingkat usaha yang dicurahkan poin kedua dan poin kelima.

\section{b. Analisa Deskriptif Kuantitatif}

1) Regresi Linear Sederhana

Regresi linear sederhana ditujukan untuk menentukan hubungan linear antara variabel bebas (X) dengan variabel terikat (Y), serta untuk memprediksi seberapa jauh perubahan nilai variabel dependen, bila nilai variabel independen diubah. Untuk melihat apakah ada pengaruh pelatihan terhadap kinerja karyawan pada PT Permata Niaga Cabang Pematangsiantar, digunakan analisis regresi linier sederhana. Penelitian ini membahas pengaruh pelatihan (X) terhadap kinerja karyawan (Y). Maka dilakukan perhitungan mengunakan program aplikasi SPSS untuk memperoleh nilai a dan b dengan notasi sebagai berikut: $\dot{Y}=a+b X$

Tabel 3

Regresi Linear Sederhana

\begin{tabular}{|c|c|c|}
\hline \multicolumn{3}{|c|}{ Regresi Linear Sederhana } \\
\hline \multirow[b]{2}{*}{ Uote } & \multicolumn{2}{|c|}{ Unstancordized Coetiticients } \\
\hline & B & Sid. Error \\
\hline 1 (Constant) & 21,448 & 3.665 \\
\hline Pole:han & 692 & 083 \\
\hline
\end{tabular}

Sumber: Hasil perhitungan SPSS for windows 17.00

Berdasarkan hasil pengolahan data pada tabel diperoleh model persamaan $\bar{Y}=21,448+0,692 \mathrm{X}$. Dari persamaan regresi tersebut dapat dijelaskan variabel pelatihan berpengaruh positif terhadap kinerja karyawan. Artinya jika variabel independen tetap dan pelatihan mengalami kenaikan 1\%, maka kinerja karyawan (Y) akan mengalami kenaikan sebesar 0,692. Koefisien bernilai positif artinya terdapat pengaruh yang positif antara pelatihan (X) terhadap kinerja karyawan (Y) pada PT Permata Niaga Cabang Pematangsiantar.
2) Analisa Koefisien Korelasi dan Koefisien Determinasi

Tabel 4

Koefisien Korelasi dan Koefisien Determinasi Model Summary'

\begin{tabular}{|c|c|c|c|c|}
\hline Hodel & $R$ & A Square & $\begin{array}{l}\text { Adjusted } \\
\text { Squase }\end{array}$ & 5id Eror or he Estimate \\
\hline 1 & $.835^{\circ}$ & .697 & .687 & 234800 \\
\hline
\end{tabular}

a. Predictors: (Constant), Pelatihan

b. Dependent Variable: Kinerja karyawan

Sumber: Hasil perhitungan SPSS for windows 17.00

Dari tabel di atas diperoleh nilai $r=0,835$ yang artinya terdapat hubungan yang sangat kuat dan positif antara pelatihan dan kinerja karyawan PT Permata Niaga Cabang Pematangsiantar. Kemudian diperoleh KD (koefisien determinasi) = 0,697 yang apabila dikalikan $100 \%$ akan memperoleh nilai sebesar $69,7 \%$, yang artinya tinggi rendahnya kinerja karyawan dapat dijelaskan sebesar $69,7 \%$ oleh pelatihan selebihnya $30,3 \%$ dijelaskan oleh faktorfaktor lain seperti motivasi, pengembangan karir, kepemimpinan, komunikasi, lingkungan kerja dan lain lain yang tidak dibahas dalam penelitian ini.

\section{3) Pengujian Hipotesis}

Pengujian ini dilakukan secara parsial untuk mengetahui apakah variabel pelatihan yang diuji berpengaruh terhadap kinerja karyawan. Jika tingkat signifikansi dibawah 0,05 maka $\mathrm{H}_{0}$ ditolak dan $\mathrm{H}_{\mathrm{a}}$ diterima, atau dengan membandingkan $t_{\text {hitung }}$ dan tabel.

Untuk menghasilkan suatu kesimpulan yang valid, maka harus dilakukan uji hipotesis. Dari hasil perhitungan koefisien korelasi diketahui bahwa pelatihan dan kinerja karyawan memiliki hubungan yang kuat dan positif, untuk menguji kebenarannya maka dilakukan pengujian hipotesis dengan menggunakan program aplikasi SPSS. Adapun pengujian positif (uji t) dapat dilihat sebagai berikut:

Tabel 5

\begin{tabular}{|l|c|c|}
\multicolumn{3}{|c|}{ Pengujian Hipotesis (Uji t) } \\
\hline \multicolumn{1}{|c|}{ Mocet } & $\mathrm{t}$ & Sig. \\
\hline Constant) & 5.853 & 000 \\
Feratinan & 0.313 & 000 \\
\hline
\end{tabular}

a. Dependent Variable: Kinerja karyawan

Sumber: Hasil perhitungan SPSS for windows 17.00

Pada tabel diatas dapat dilihat bahwa hipotesis $\mathrm{H}_{0}$ ditolak, jadi terdapat pengaruh yang signifikan variabel pelatihan terhadap kinerja karyawan, dimana nilai signifikansi pada variabel ini $0,000<$ 0,05 . Dari perhitungan tabel $17, \mathrm{t}_{\text {hitung }}$ sebesar 8,313 lebih besar dari $\mathrm{t}_{\text {tabel }}$ sebesar 2,042, maka $\mathrm{H}_{0}$ ditolak dan $\mathrm{H}_{\mathrm{a}}$ diterima, artinya pelatihan berpengaruh positif terhadap kinerja karyawan pada PT Permata Niaga Cabang Pematangsiantar. 


\section{Evaluas}

a. Pelatihan Pada PT Permata Niaga Cabang Pematangsiantar

Berdasarkan indikator yang digunakan oleh penulis, diperoleh hasil penelitian yang menyatakan bahwa pelatihan pada PT Permata Niaga dapat dikatakan baik. Hal tersebut dibuktikan berdasarkan kuesioner yang dibagikan oleh penulis, dan diperoleh nilai rata-rata jawaban sebesar 3,65 yang dinilai baik. Tetapi terdapat indikator yang apabila dilihat dari perolehan nilai rata-ratanya dinilai kurang baik. Indikator yang dimaksud yaitu pada indikator kedua pada poin ketiga yang memperoleh nilai rata-rata sebesar 3,25. Pada indikator ini dijelaskan bahwa para senior yang ditunjuk sebagai instruktur kurang mampu dalam memberikan pelatihaan kepada karyawan baru. Karyawan senior memang telah memilki pengetahuan dan paham betul tentang apa yang diperlukan dalam melaksanakan tugas dan pekerjaannya, tetapi didalam memberikan pelatihan (transfer knowledge) kepada karyawan baru, karyawan senior kurang ahli. Untuk mengatasi masalah tersebut maka perusahan dapat memberikan pelatihan khusus kepada karyawan senior dalam hal menjadi seorang pelatih untuk karyawan baru tersebut melalui kegiatan pelatihan di lembaga pelatihan yang ditentukan oleh perusahaan.

Kemudian kendala dan kekurangan juga terdapat pada indikator ketiga pada poin pertama dan kedua. Pada poin pertama diperoleh nilai rata-rata sebesar 3,25 dan pada poin kedua diperoleh nilai rata-rata sebesar 3,34. Untuk mengatasinya permasalahan tersebut, maka perusahaan sebaiknya memberikan apresiasi terhadap karyawannya yang telah mengikuti proses pelatihan yang diadakan oleh perusahaan. Apabila mereka mendapatkan nilai yang baik pada saat mengikuti pelatihan pelatihan maka perusahaan akan memberikan promosi ataupun penghargaan sehingga mereka akan merasa tertarik untuk mengikuti pelatihan dan berusaha meningkatkan keahlian serta keterampilan mereka masing-masing.

\section{b. Kinerja Karyawan PT Permata Niaga Cabang Pematangsiantar}

PT Permata Niaga Cabang Pematangsiantar mencapai tujuan organisasi salah satunya melalui kinerja karyawannya. Kinerja karyawan sudah baik berdasarkan indikator kinerja yaitu kemampuan individu, tingkat usaha yang dicurahkan, dan dukungan organisasi. Dikatakan demikian karena dapat dilihat dari total nilai rata-rata keseluruhan yang diperoleh yaitu sebesar 4,31. Namun pada indikator kemampuan individu poin keempat, tingkat usaha yang dicurahkan poin kedua, ketiga dan kelima nilai rata-rata nya masih dibawah nilai ratarata keseluruhan indikator kinerja.

Pada indikator kemampuan individu poin keempat, yaitu dari segi kehadiran, nilai rata-rata yang diperoleh sebesar 4,25. Dalam hal ini, perusahaan dapat mengatasinya dengan memberikan sanksi yang tegas terhadap karyawan yang datang terlambat ke kantor. Ini semua dilakukan agar semua karyawan datang ke kantor tepat pada waktunya.

Selanjutnya pada indikator tingkat usaha yang dicurahkan pada poin kedua nilai rata-rata yang diperoleh sebesar 4,22. Untuk mengatasi hal ini sebaiknya pimpinan perusahan mengadakan rapat atau pertemuan setiap minggu, dengan demikian apabila ada permasalahan antar rekan kerja dapat diselesaikan dan kerjasama antar rekan kerja dapat ditingkatkan sehingga mendapatkan hasil yang memuaskan. Kemudian pada poin ketiga dalam hal bekerja sama diperoleh nilai rata-rata sebesar 4,25. Untuk mengatasi hal ini sebaiknya perusahaan mengadakan kegiatan-kegiatan olahraga maupun kegiatan yang bersifat kerjasama. Kegiatan tersebut dapat dilaksanakan pada akhir pekan, pada hari ulang tahun perusahan atau pada saat hari libur. Dengan demikian kerjasama antar rekan kerja di dalam perusahaan dapat ditingkatkan lagi. Kemudian pada kategori menyelesaikan pekerjaan tepat pada waktu diperoleh nilai rata-rata sebesar 4,22. Untuk mengatasi hal ini maka pimpinan perusahaan harus memotivasi semua karyawan dengan memberikan apresiasi atau penghargaan kepada karyawan yang menyelesaikan pekerjaannya dengan tepat waktu.

\section{KESIMPULAN DAN SARAN}

\section{Kesimpulan}

a. Dari seluruh pengolahan kuesioner tentang pelatihan memiliki nilai rata-rata keseluruhan sebesar 3,65 dan dikategorikan setuju atau baik. Dari data tersebut diperoleh nilai rata tertinggi yaitu 4,03 pada indikator materi yang diberikan pada poin kedua, kemudian pada indikator instruktur pada poin pertama dan indikator tempat dan fasilitas poin ketiga. Namun pada indikator instruktur pada poin ketiga dan pada indikator peserta poin pertama belum optimal dikarenakan nilai rata-rata yang diperoleh sebesar 3,25 yang dikategorikan kurang setuju.

b. Dari hasil pengolahan kuesioner tentang kinerja karyawan memiliki nilai keseluruhan 4,31 dan dikategorikan sangat setuju atau sangat baik. Adapun nilai rata-rata tertinggi yaitu terdapat pada indikator dukungan organisasi poin pertama sebesar 4,41. Namun terdapat nilai terendah 4,22 terdapat pada indikator tingkat usaha yang dicurahkan poin kedua dan poin kelima.

c. Hasil pengujian regresi adalah $\hat{Y}=21,448+$ $0,692 \mathrm{X}$, berarti terdapat pengaruh positif variabel pelatihan (X) dan kinerja karyawan (Y) pada PT Permata Niaga Cabang Pematangsiantar.

d. Melalui analisa koefisien korelasi dan koefisien determinasi dengan menggunakan program aplikasi SPPS diperoleh diperoleh nilai $r=0,835$ yang artinya terdapat hubungan yang sangat kuat dan positif antara pelatihan dan kinerja karyawan PT Permata Niaga Cabang Pematangsiantar. Kemudian diperoleh KD (koefisien determinasi) $=0,697$ yang apabila dikalikan $100 \%$ akan memperoleh nilai sebesar $69,7 \%$, yang artinya tinggi rendahnya kinerja karyawan dapat 
dijelaskan sebesar $69,7 \%$ oleh pelatihan selebihnya $30,3 \%$ dijelaskan oleh faktor-faktor lain seperti motivasi, pengembangan karir, kepemimpinan, komunikasi, lingkungan kerja dan lain lain yang tidak dibahas dalam penelitian ini.

e. Melalui perhitungan uji hipotesis, terdapat pengaruh yang positif dan signifikan antara variabel pelatihan terhadap kinerja karyawan, dimana nilai signifikansi pada variabel ini 0,000 $<0,05$. Kemudian melalui uji $\mathrm{t}$ dengan taraf signifikansi $5 \%$ disimpulkan bahwa nilai $\mathrm{t}_{\text {hitung }}$ sebesar 8,313 lebih besar dari $t_{\text {tabel }}$ sebesar 2,042, maka $\mathrm{H}_{0}$ ditolak dan $\mathrm{H}_{\mathrm{a}}$ diterima, artinya pelatihan berpengaruh terhadap kinerja karyawan pada PT Permata Niaga Cabang Pematangsiantar.

\section{Saran}

a. Agar pelaksanaan pelatihan dapat berjalan dengan baik maka pada indikator instruktur, perusahaan dapat memberikan pelatihan khusus kepada karyawan senior dalam hal menjadi seorang pelatih untuk karyawan baru tersebut melalui kegiatan pelatihan di lembaga pelatihan yang ditentukan oleh perusahaan. Selanjutnya pada indikator peserta, perusahaan sebaiknya memberikan apresiasi terhadap karyawannya yang mengikuti pelatihan agar karyawan lebih termotivasi.

b. Agar kinerja karyawan dapat ditingkatkan maka segi kehadiran, perusahaan dapat mengatasinya dengan memberikan sanksi yang tegas terhadap karyawan yang datang terlambat ke kantor. Selanjutnya pada dalam hal bekerja sama, pimpinan perusahan dapat mengadakan mengadakan rapat atau pertemuan setiap minggu dan kegiatan-kegiatan olahraga maupun kegiatan yang bersifat kerjasama. Kemudian pada kategori menyelesaikan pekerjaan tepat pada waktu.
Untuk mengatasi hal ini maka pimpinan perusahaan harus memotivasi semua karyawan agar menyelesaikan pekerjaannya dengan tepat waktu.

c. Sehubungan dengan keterbatasan-keterbatasan yang ada pada penulis, penelitian ini masih terdapat kelemahan-kelemahan dan belum dapat mengungkap seluruh variabel yang dapat mempengaruhi kinerja karyawan pada PT Permata Niaga Cabang Pematangsiantar. Sebagai bahan masukan untuk penelitian selanjutnya, perlu memperbanyak variabel penelitian seperti motivasi, pengembangan karir, kepemimpinan, komunikasi, lingkungan kerja dan lain lain.

\section{E. DAFTAR PUSTAKA}

Dessler, Gary, 2003, Human Resource Management, Ninth Edition, PHIPE, Prentice Hall.

Flippo, 2000, Personal Management, Singapore: Mc Grow Hill.

Hasibuan, Malayu S.P., 2000, Manajemen Sumber Daya Manusia, Yogyakarta: BPFE.

Mathis, Robert L., dan John H. Jackson, 2006, Human Resources Management, Edisi Kesepuluh, Jakarta: Salemba Empat.

Mondy, R. Wayne, 2008, Manajemen Sumber Daya Manusia, Jilid 1, Edisi Kesepuluh, Jakarta: Erlangga.

Nasution, S, 2002, Berbagai Pendekatan dalam Proses Belajar Mengajar, Jakarta: Bina Aksara.

Rivai, Veithzal, 2004, Manajemen Sumber Daya Manusia Untuk Perusahaan, Cetakan Pertama, Jakarta: PT Raja Grafindo.

Simamora, Henry, 2002, Manajemen Sumber Daya Manusia, Yogyakarta: BP. STIE.

Sudewa,

Wira www.slideshare.net/wirasudewa90/contohproposalskripsi, analisis tahun 2014. 